\title{
Sistem Informasi Manajemen Pada Jasa Expedisi Pengiriman Barang Berbasis Web
}

\author{
Cahya Vikasari*1 \\ ${ }^{1}$ Politeknik Negeri Cilacap; Jl.Dr.Soetomo No.1 Sidakaya Cilacap, telp/fax.(0282)537992 \\ ${ }^{1}$ Jurusan Teknik Informatika, Cilacap \\ *11 cvikasari@gmail.com
}

\begin{abstract}
The freight forwarding service is a promising business so many new companies are opening this business. Business Delivery of goods is the impact of other businesses that require services expedition. Some of the problems that can happen is data loss, data error or lack of complete data delivery of goods, the division of work courier is also a complicated matter, and tracking of the delivery of goods is difficult. Application development to overcome the problem is building information management of web-based freight forwarding with waterfall software development method and using the concept of Unified Modeling Language (UML). Use of the application can reduce the risk of data loss due to less orderly administration, error data or lack of data delivery of goods because the data is stored centrally on the server. Distribution of courier in goods delivery can be done more easily. Use of this application provides information about tracking the delivery of goods so that the delivery process can be tracked its existence.
\end{abstract}

Keywords-expedisi, UML, waterfall

\section{Abstrak}

Jasa pengiriman barang merupakan bisnis yang menjanjikan sehingga banyak perusahaan baru yang membuka usaha ini. Bisnis Pengiriman barang merupakan imbas dari bisnis yang lain yang memerlukan jasa expedisi. Beberapa permasalahan yang bisa terjadi yaitu kehilangan data, kekeliruan data atau kurang lengkapnya data pengiriman barang, pembagian kerja kurir juga merupakan hal rumit, serta pelacakan dari pengiriman barangnya sulit dilakukan. Pembangunan aplikasi untuk mengatasi masalah tersebut yaitu membangun informasi manajemen ekspedisi pengiriman barang berbasis web dengan metode pengembangan perangkat lunak waterfall dan menggunakan konsep Unified Modelling Language (UML). Penggunaan aplikasi dapat mengurangi resiko kehilangan data karena kurang tertib administrasi, kekeliruan data atau kurang lengkapnya data pengiriman barang karena data tersimpan terpusat pada server. Pembagian kurir dalam pengiriman barang dapat dilakukan dengan lebih mudah. Penggunaan aplikasi ini memberikan informasi tentang tracking pengiriman barang sehingga proses pengiriman dapat dilacak keberadaannya.

Kata kunci-expedisi, UML, waterfall

\section{PENDAHULUAN}

$\mathrm{T}$ Eknologi informasi sangat dibutuhkan disegala bidang untuk mendukung proses bisnis yang ada dalam perusahaan. Salah satu kemajuan teknologi tersebut dengan adanya komputer. Komputer selain membuat pekerjaan yang dikerjakan oleh manusia lebih praktis, cepat dan mudah, komputer juga dapat dihubungkan dengan internet sehingga dapat diakses oleh masyarakat [1]. Pergerakan ekonomi terus tumbuh di Indonesia salah satunya adalah dalam 
bidang jasa expedisi pengiriman barang. Pada saat ini pengiriman barang menjadi hal yang tidak asing lagi karena para pelaku bisnis sekarang ini banyak bertransaksi di internet. Orang-orang akan semakin mudah untuk berbelanja walaupun penjualan dan pembelian tidak saling bertemu langsung. Itulah sebabnya jasa pengiriman barang semakin dibutuhkan. Peluang bisnis dan prospek jasa pengiriman barang masih sangat bagus dan terus berkembang [2]. Banyak pengusaha yang mulai melirik usaha expedisi pengiriman barang antara lain karena imbas dari pertumbuhan online shoping yang ada di Indonesia sehingga jasa pengiriman barang ini seperti rantai bisnis yang tidak terpisahkan dari usaha yang lain. Selain imbas dari online shoping yang ada, usaha kecil menengah yang ingin mendistribusikan produknya, masyarakat dengan berbagai kegiatan juga sangat membutuhkan jasa expedisi ini.

Kegiatan yang ada pada bisnis ekspedisi pengiriman barang salah satunya adalah administrasi dalam pengelolaan data pengiriman barang. Kendala yang terjadi yaitu kehilangan data karena kurang tertib administrasi, kekeliruan data atau kurang lengkapnya data pengiriman barang akan membuat jasa ekspedisi ini terhambat dalam pengiriman barang. Pembagian kerja masing-masing kurir merupakan hal rumit sehingga bagian admin harus mengetahui kurir yang dapat melakukan kegiatan pengiriman barang. Pengiriman barang bisa terjadi tepat waktu atau jika terjadi kendala maka bisa menyebakan lama dalam pengiriman. Hal ini membuat konsumen ingin mengetahui tracking dari pengiriman barangnya jika belum menggunakan sistem maka proses pelacakan barang akan sulit dilakukan. Hal inilah yang menyebabkan seringnya terjadi kesalahpahaman antara perusahaan dan kurir ataupun dengan operator yang dapat mengakibatkan kerugian waktu dan biaya.

Dengan permasalahan yang ada penulis memiliki ide untuk membuat sistem berbasis web dalam ekspedisi pengiriman barang, Aplikasi web yang dibuat memberikan informasi mengenai perjalanan barang dari daerah yang satu ke daerah yang lain sehingga pihak penyedia layanan atau pemilik barang dapat menggunakan informasi tersebut (tracking), memuat berbagai informasi pengiriman terkini, memuat informasi tarif, memuat profile dan memberikan informasi lain yang berguna bagi pelanggan. Hal ini dapat meminimalisir hilangnya barang, atau kecelakaan kerja lainnya dan barang yang dikirimkan dapat sampai di tempat tujuan sesuai dengan rencana awal pengiriman [3].

\section{METODE PENELITIAN}

\subsection{Tahap Pengembangan Sistem}

Tahap pengembangan sistem dalam pembangunan sistem informasi manajemen ekspedisi pengiriman barang menggunakan metode pengembangan System Development Life Cycle (SDLC) dengan model proses atau paradigm waterfall. Dimana hal ini menggambarkan pendekatan yang sistematis dan juga berurutan pada pengembangan perangkat lunak, dimulai dengan spesifikasi kebutuhan pengguna lalu berlanjut melalui tahapan-tahapan perencanaan (planning), permodelan (modeling), konstruksi (construction), serta penyerahan sistem ke para pelanggan/pengguna (deployment), yang diakhiri dengan dukungan pada perangkat lunak lengkap yang dihasilkan [4]. Tahapan pada waterfall model mengambil kegiatan dasar yang digunakan dalam hampir semua pengembangan perangkat lunak, sehingga lebih mudah untuk dipahami terlebih bila hanya digunakan dalam mengembangkan perangkat lunak yang tidak begitu besar dan kompleks. Tahap-tahap utama dari waterfall model adalah sebagai berikut [5].

\section{1.1 Analisis Kebutuhan}

\section{A. Analisis Kebutuhan Pengguna}

Hasil analisa kebutuhan pengguna dapat dilihat pada tabel 1 . 
Tabel 1. Analisa Kebutuhan Sistem

\begin{tabular}{|c|l|}
\hline User & \multicolumn{1}{|c|}{ Fungsi } \\
\hline Pegawai & $\begin{array}{l}\text { Pegawai dapat melakukan login, } \\
\text { mengolah data user, pengolahan } \\
\text { data pegawai, pengolahan data } \\
\text { kurir, pengolahan data member, } \\
\text { pengolahan data pengiriman, } \\
\text { pengolahan data tracking, } \\
\text { pengolahan data tarif, pengolahan } \\
\text { data diskon, laporan. }\end{array}$ \\
\hline Kurir & $\begin{array}{l}\text { Kurir mempunyai hak akses untuk } \\
\text { login, mengelola data kurir, } \\
\text { mengelola data tracking. }\end{array}$ \\
\hline Member & $\begin{array}{l}\text { Member dapat melakukan login } \\
\text { dan mengelola data member. }\end{array}$ \\
\hline \multirow{3}{*}{ Pelanggan } & $\begin{array}{l}\text { Mengesahkan sarmut unit dan } \\
\text { dapat melihat melihat draft } \\
\text { sarmut, jadwal audit, sarmut unit, } \\
\text { hasil sarmut unit, rekap checklist } \\
\text { audit sarmut, dan report intern } \\
\text { audit deviation. }\end{array}$ \\
\hline
\end{tabular}

B. Analisis Kebutuhan Jaringan

Analisis kebutuhan antarmuka jaringan dalam sistem informasi manajemen ekspedisi pengiriman barang dapat dilihat pada tabel 1 .

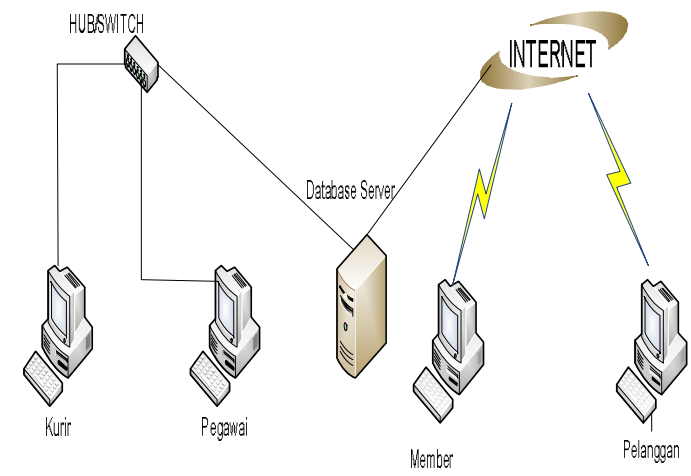

Gambar 1. Analisis Kebutuhan Antarmuka Jaringan

\section{2 Perancangan}

\section{2. $3 U M L$}

Unified Modelling Language (UML) adalah sebuah "bahasa" yang telah menjadi standar dalam industri untuk visualisasi merancang dan mendokumentasikan sistem piranti lunak. UML menawarkan sebuah standar untuk merancang model sebuah sistem. Dengan menggunakan UML dapat dibuat model untuk semua jenis aplikasi piranti lunak, dimana aplikasi tersebut dapat berjalan pada piranti keras, sistem operasi dan jaringan apapun, serta ditulis dalam bahasa pemrograman apapun [7]. 


\section{3. 1 Usecase}

Dalam pembuatan aplikasi sistem informasi manajemen ekspedisi pengiriman barang menggunakan konsep perancangan Unified Modelling Language (UML) dengan menggunakan usecase diagram, adapun gambaran sistem atau use case diagram yang akan dikembangkan pada gambar 3.

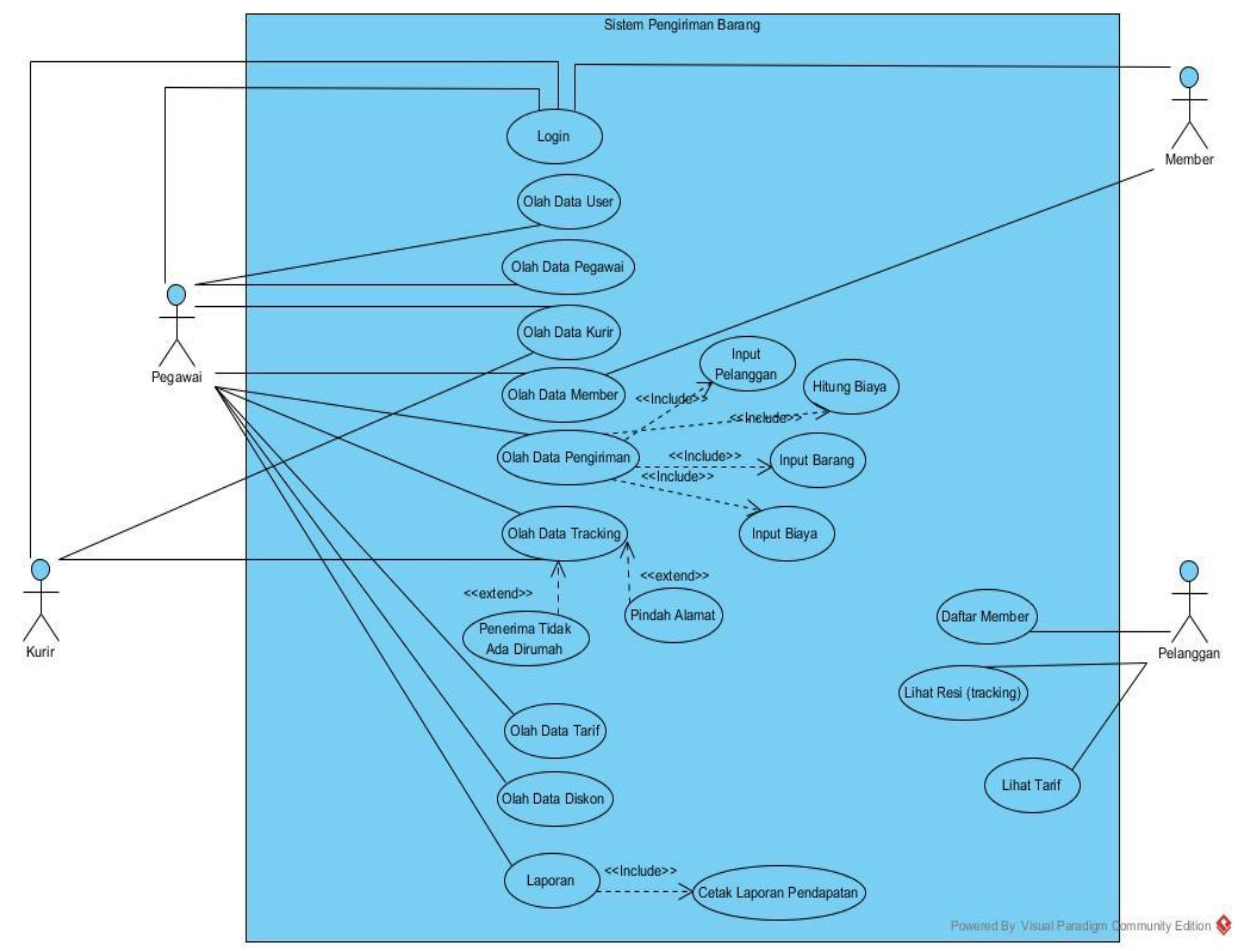

Gambar 2. Usecase Diagram

\section{3. 2 Sequence Diagram}

Sequence Diagram menggambarkan kelakuan objek pada use case dengan mendeskripsikan waktu hidup objek dan pesan yang dikirimkan dan diterima antar objek.

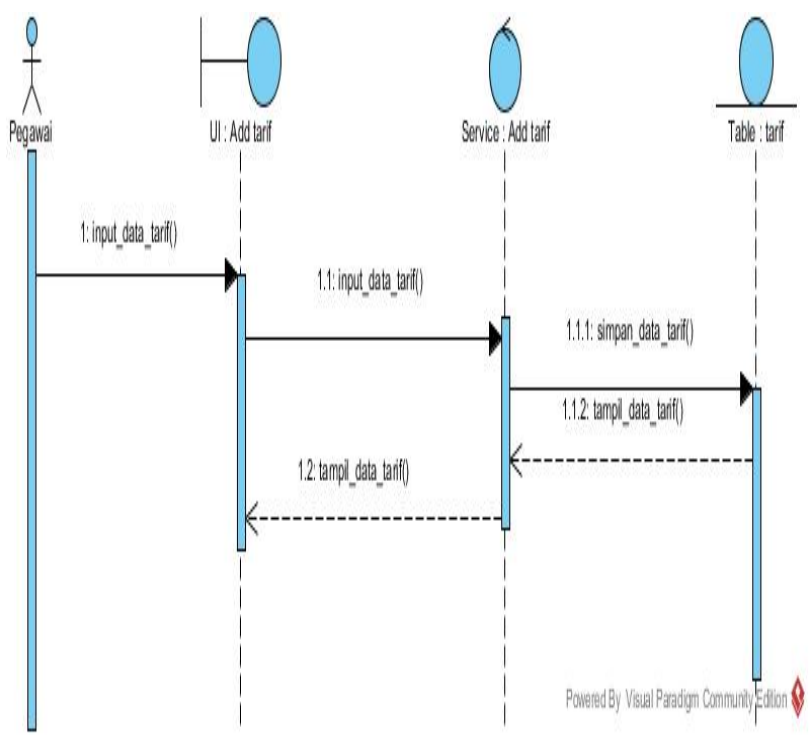

Gambar 3. Sequence Input Tarif 


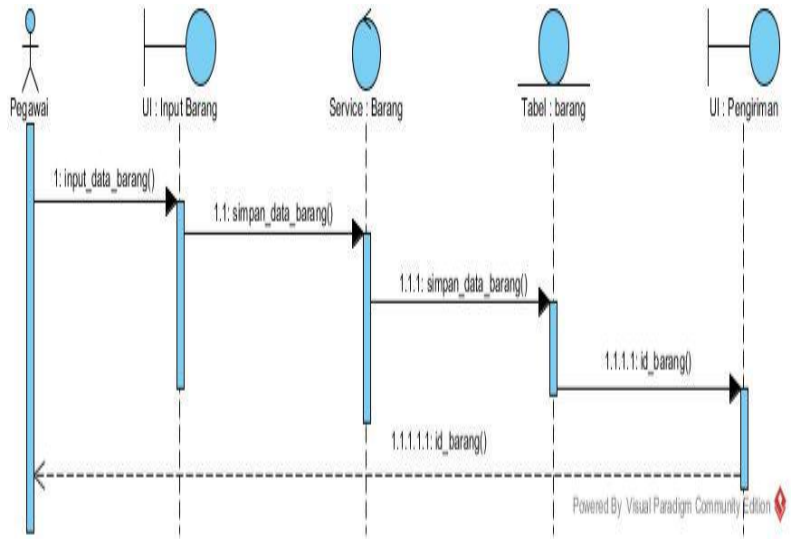

Gambar 4. Sequence Insert Pengiriman Barang

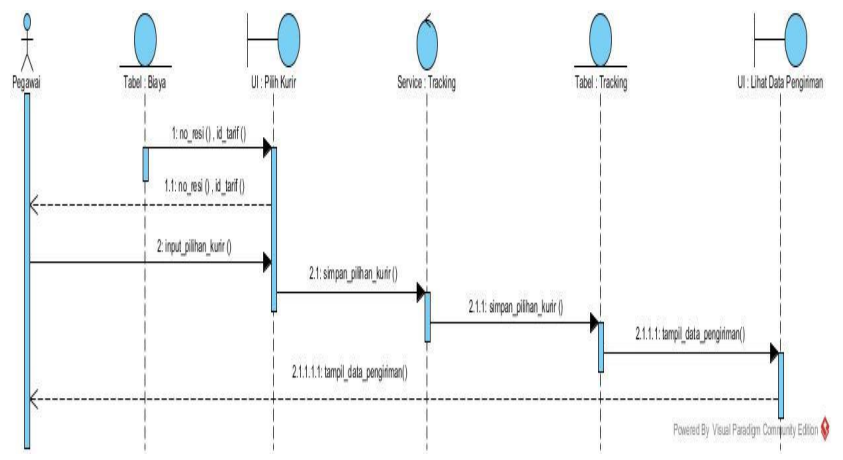

Gambar 5. Sequence Insert Tracking

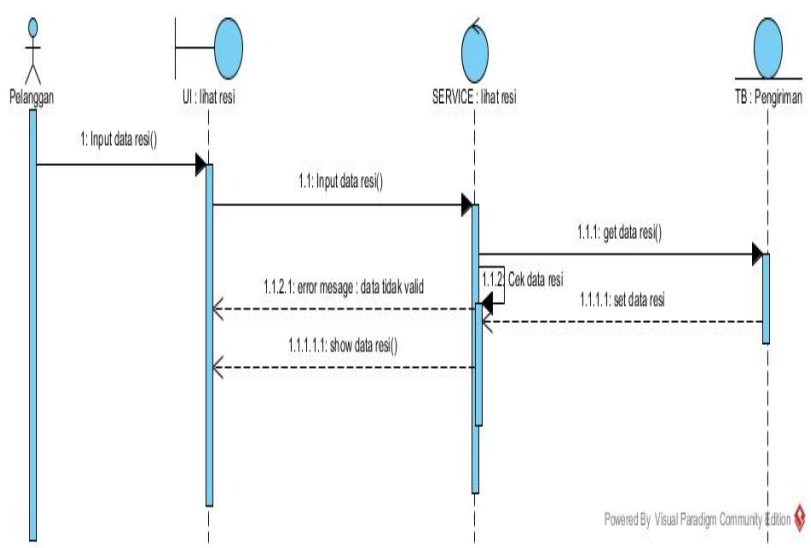

Gambar 6. Sequence Lihat Resi 


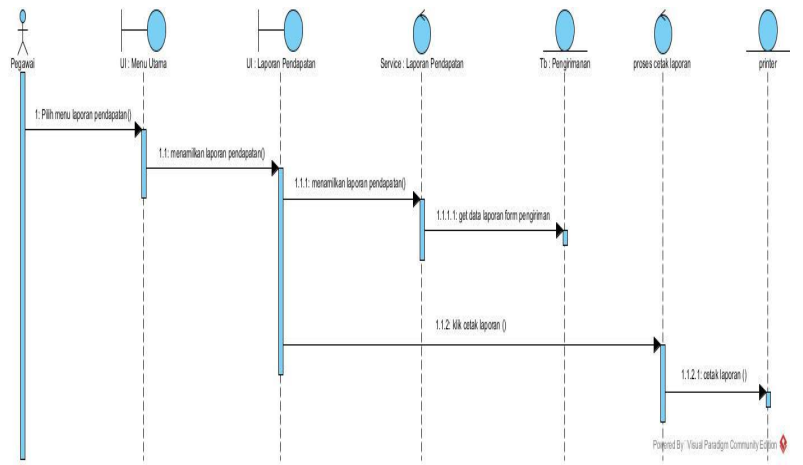

Gambar 7. Sequence Cetak Laporan Pendapatan

\subsubsection{Class Diagram}

Diagram Class atau kelas diagram menggambarkan struktur sistem dari segi pendefinisian kelas-kelas yang akan dibuat untuk membangun sistem. Di bawah ini merupakan gambar class diagram untuk menggambarkan struktur sistem yang akan dibuat untuk membangun sistem informasi manajemen ekspedisi pengiriman barang berbasis web.

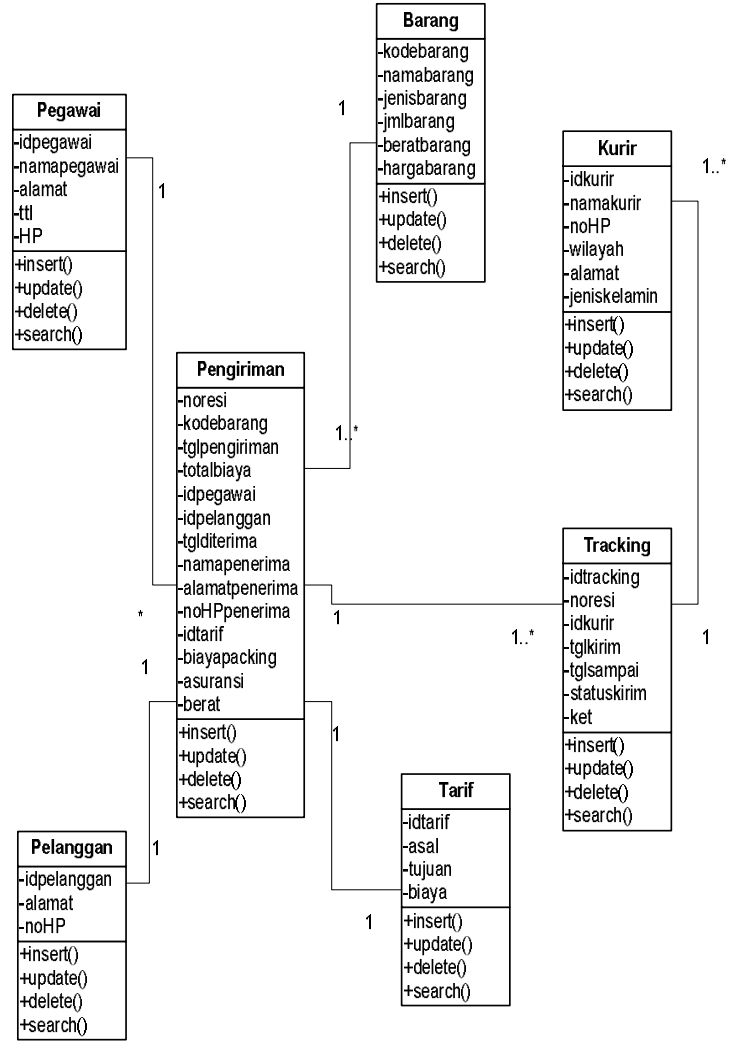

Gambar 8. Class Diagram

\section{HASIL DAN PEMBAHASAN}

Implementasi merupakan suatu perwujudan/penerapan dari rancangan sistem yang telah dibuat kedalam suatu program sehingga fungsi dari masing-masing proses akan terlihat [6].Pembahasan terhadap hasil penelitian mengenai sistem informasi manajemen expedisi 
pengiriman barang berbasis web yang diperoleh disajikan dalam bentuk uraian teoritik secara kualitatif. Hasil dan ppembahasan sistem informasi manajemen expedisi pengiriman barang berbasis web sebagai berikut:

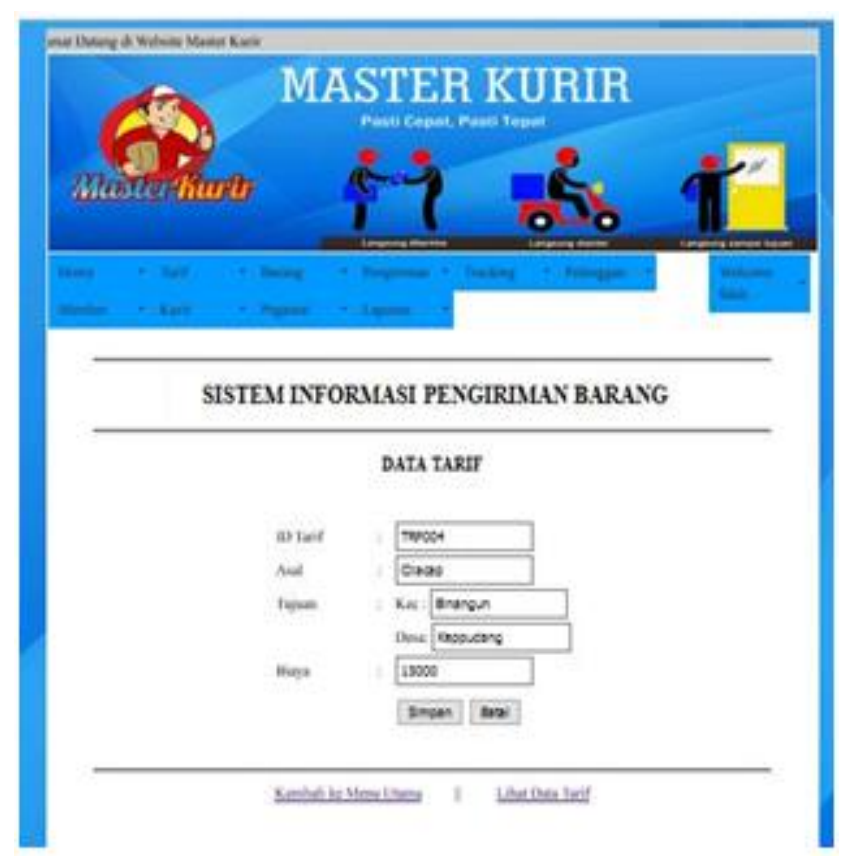

Gambar 9. Tampilan Pengelolaan Data Tarif Pengiriman Barang

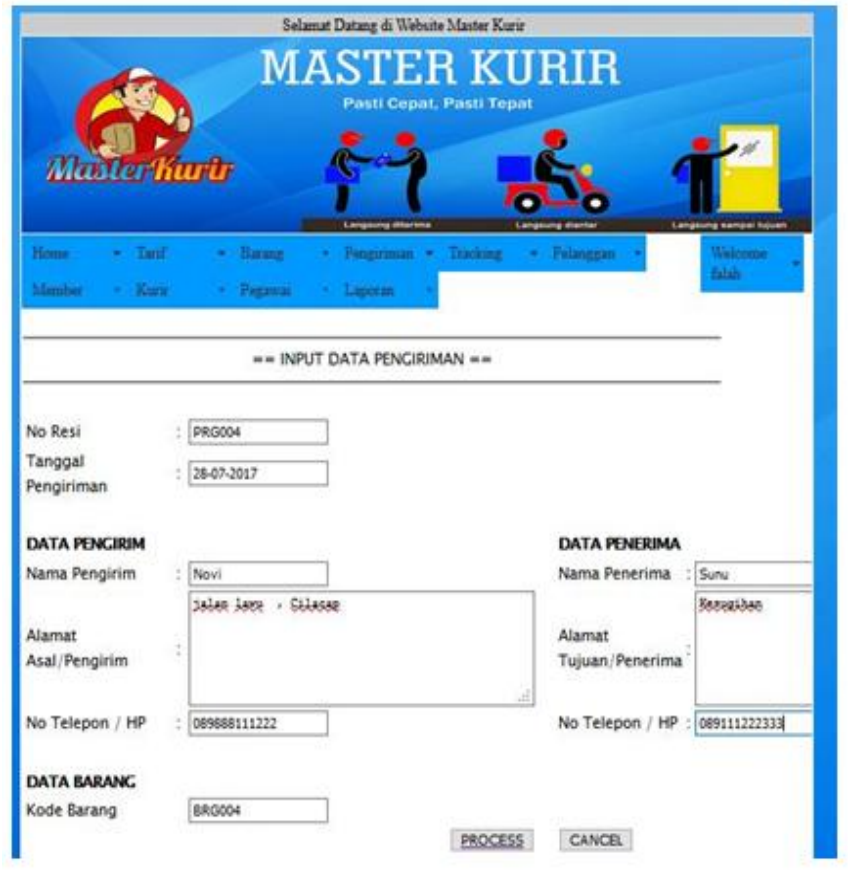

Gambar 10. Tampilan Pengelolaan Data Pengiriman Barang 


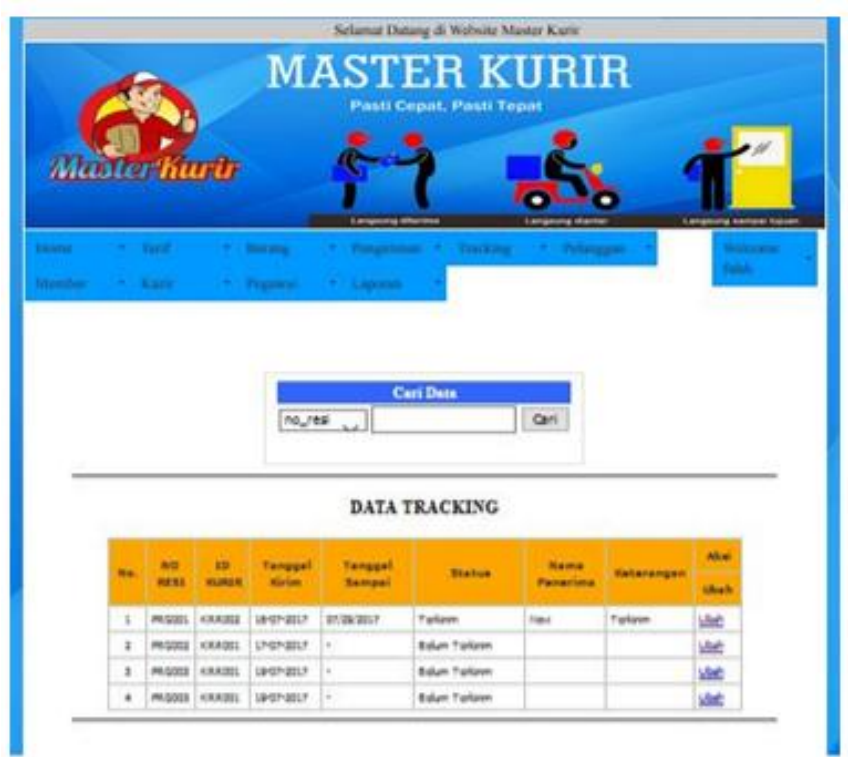

Gambar 11. Tampilan Pengelolaan Data Tracking

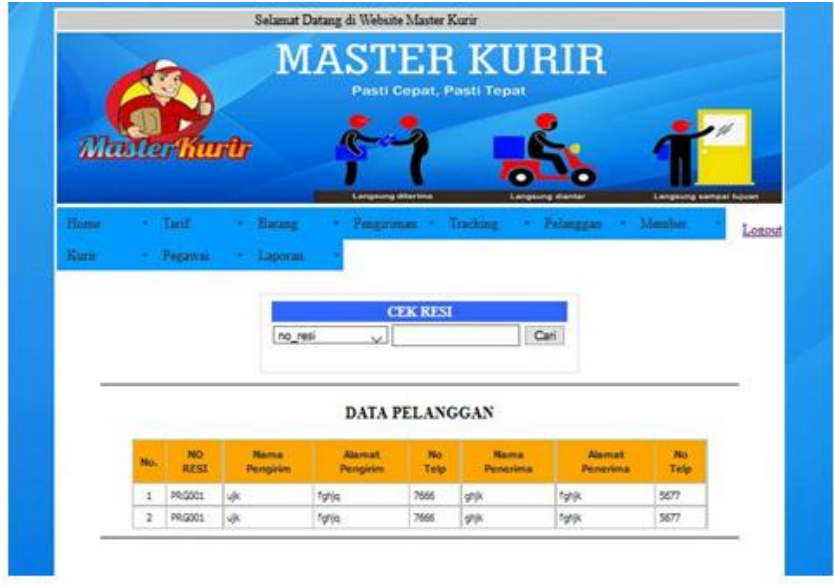

Gambar 12. Tampilan Pengelolaan Data Tarif Pengiriman Barang

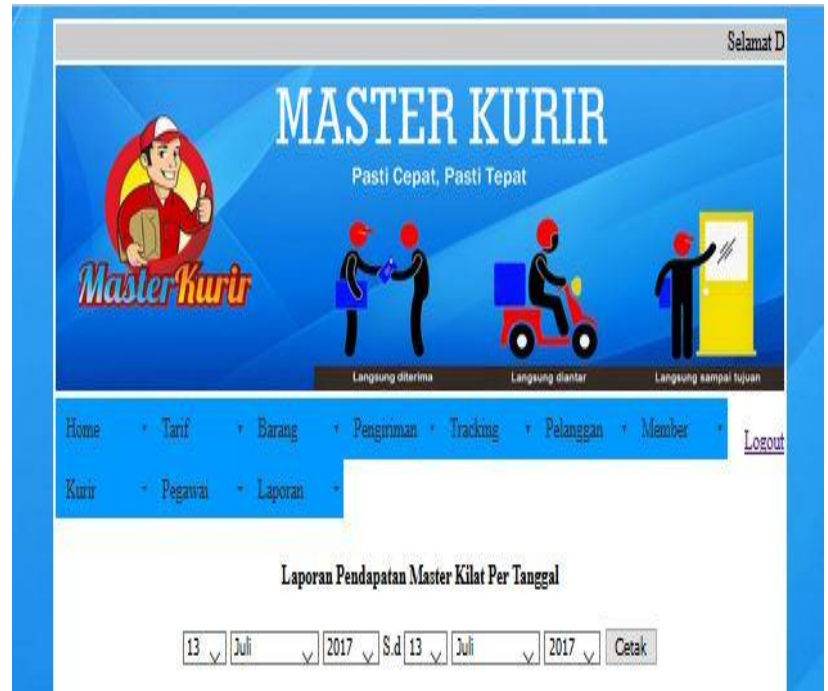

Gambar 13. Tampilan Pengelolaan Data Laporan Pendapatan. 


\section{KESIMPULAN}

Berdasarkan hasil pembahasan tentang sistem informasi manajemen expedisi pengiriman barang berbasis web, Diperoleh kesimpulan sebagai berikut:

1. Penggunaan aplikasi sistem informasi manajemen expedisi pengiriman barang ini dapat mengurangi resiko kehilangan data karena kurang tertib administrasi, kekeliruan data atau kurang lengkapnya data pengiriman barang karena data tersimpan terpusat pada server.

2. Pembagian kurir dalam pengiriman barang dapat dilakukan dengan lebih mudah.

3. Penggunaan aplikasi ini memberikan informasi tentang tracking pengiriman barang sehingga proses pengiriman dapat dilacak keberadaannya.

\section{SARAN}

Setelah sistem informasi manajemen expedisi pengiriman barang berbasis web ini dibuat, ada beberapa saran yang berhubungan dengan sistem informasi ini untuk kesempurnaan pengembangan sistem bagi penulis selanjutnya dimasa mendatang yaitu:

1. Aplikasi dapat dikembangkan berbasis android sehingga aplikasi dapat terinstall langsung ke handphone pengguna.

2. Aplikasi dapat dikembangkan dengan fitur monitoring langsung misalnya berhubungan dengan online shop sehingga online shop dapat langsung terupdate status pengirimannya.

\section{UCAPAN TERIMA KASIH}

Dengan penuh rasa syukur kehadirat Allah SWT dan setelah itu tanpa menghilangkan rasa hormat yang mendalam, saya selaku penyusun dan penulis mengucapkan terima kasih yang sebesarbesarnya kepada pihak-pihak yang telah membantu penulis untuk menyelesaikan penelitian ini, penulis mengucapkan terima kasih kepada:

1. Allah SWT, yang telah memberikan segala kemudahan, kelancaran dan kesehatan hingga sekarang.

2. Soedihono, Dipl.TT.ST.MT, selaku Direktur Politeknik Negeri Cilacap.

3. Muhamad Yusuf, ST., M.T selaku Wakil Direktur II Politeknik Negeri Cilacap.

4. Nur Wahyu Rahadi, S.Kom., M.Eng, selaku kektua jurusan teknik informatika Politeknik Negeri Cilacap.

\section{DAFTAR PUSTAKA}

[1] Nur Dwi Satika. 2014, Sistem Informasi Pengiriman Barang Berbasis Web dengan Metode Transshipment, Skripsi, Program Studi Sistem Informasi, Sekolah Tinggi Teknologi Indonesia, Tanjungpinang.

[2]Harry Dhika, Lukman, Aswin Fitriansyah. 2016, Perancangan Sistem Informasi Jasa Pengiriman Barang Berbasis Web, Jurnal Simetris, Vol 7 No 1 April 2016 Issn: 2252-4983, Hal 51-58.

[3] Pressman, Roger S. 2012, Rekayasa Perangkat Lunak - Buku Satu, Pendekatan Praktisi, Edisi 7, Andi, Yogyakarta.

[4] Sommerville, Ian. 2003, Software Engineerin,, 6th edition, Yuhilza Hanum (penterjemah), Erlangga, Jakarta. 
[5]Prasetya, E., 2006, Case Based Reasoning untuk Mengidentifikasi Kerusakan Bangunan, Tesis, Program Pasca Sarjana Ilmu Komputer, Univ. Gadjah Mada, Yogyakarta.

[6]Nugroho, A., 2005, Analisis dan Perancangan Sistem Informasi dengan Metodologi Berorientasi Objek, Penerbit Informatika, Bandung.

[7] Ade Hendini. 2016, Pemodelan Uml Sistem Informasi Monitoring Penjualan dan Stok Barang (Studi Kasus: Distro Zhezha Pontianak, Jurnal Khatulistiwa Informatika Program Studi Manajemen Informatika Amik "Bsi Pontianak", Vol. IV, No. 2 Desember 2016, hal 107-116 